\title{
Systematic Review: Cardiac Metastasis of Lingual Squamous Cell Carcinoma
}

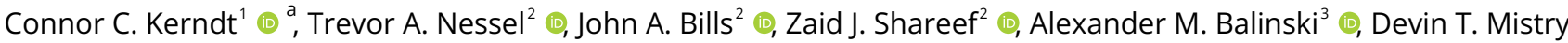 \\ 1 Department of Internal Medicine, Spectrum Health/Michigan State University College of Human Medicine, Grand Rapids, Michigan, USA, 2 Michigan \\ State University College of Osteopathic Medicine, East Lansing, Michigan, USA, ${ }^{3}$ Oakland University William Beaumont School of Medicine, Rochester, \\ Michigan, USA, ${ }^{4}$ Department of Otolaryngology, Metro Health Hospital-University of Michigan, Wyoming, Michigan, USA \\ Keywords: cancer, cardiac metastasis, squamous cell carcinoma, tongue \\ https://doi.org/10.51894/001c.27297
}

\section{Spartan Medical Research Journal}

Vol. 6, Issue 2, 2021

\section{INTRODUCTION}

Lingual squamous cell carcinoma (LSCC) is an aggressive malignancy that carries significant mortality risk and the potential for cardiac metastasis. The authors performed a systematic review designed to characterize disease progression of LSCC cardiac metastasis by evaluating patient demographics, characteristics, management, and clinical outcomes.

\section{METHODS}

Two authors independently screened articles in Embase, PubMed, and Cochrane Database of Systematic Reviews up until December 2019 for study eligibility. Demographic data, patient symptomatology, imaging findings, management strategies, and patient outcomes were obtained and analyzed. The Oxford Centre for Evidence Based Medicine (OCEBM) Levels of Evidence categorization was implemented to determine the quality of studies selected in this review.

\section{RESULTS}

From this review, a total of 28 studies met inclusion criteria and received an OCEBM Level 4 evidence designation. Thirty-one patients were identified with cardiac metastasis from LSCC. Shortness of breath (29.0\%) and chest pain (29.0\%) were the most common presenting symptoms, and pericardial effusion (29.2\%) and right ventricular outflow tract obstruction (25.0\%) were the predominant echocardiogram findings. Cardiac metastases most often presented in the right ventricle (56.7\%), followed by the left ventricle (43.3\%). Palliative intervention (68.2\%) or chemotherapy (40.9\%) were typically implemented as treatments. All sample patients expired within one year of metastatic cancer diagnosis in cases that reported mortality outcomes.

\section{CONCLUSIONS}

Patients presenting with shortness of breath, tachycardia, and a history of squamous cell carcinoma of the tongue may indicate evaluation for LSCC cardiac metastasis. Although LSCC cardiac metastases typically favor the right and left ventricles, they are not exclusive to these sites. Palliative care may be indicated as treatment due to high mortality and overall poor outcomes from current interventions.

\section{INTRODUCTION}

Cancer of the oropharynx (i.e., part of the throat at the back of the mouth behind the oral cavity) is one of the most frequently diagnosed cancers worldwide, representing the seventh largest incidence burden of new cancer in men and fourteenth amongst women. ${ }^{1-4}$ Lingual squamous cell carcinoma (LSCC) accounts for approximately $3.0 \%$ of oropharyngeal carcinomas, ${ }^{4}$ typically affecting male smokers older than 45 years of age. ${ }^{5,6}$ Although LSCC is rare, global rates have been shown to increase from $0.4 \%$ to $3.3 \%$ during recent years, and there is an increasing incidence in the young 
female population. ${ }^{7}$

LSCC primarily confers metastatic risk to the lungs, heart, and bones, although it has demonstrated the ability to metastasize to nearly all organ systems. ${ }^{3}$ As a result, presentations of metastatic LSCC are exceptionally variable and contingent on the site of metastasis. It has also been estimated that metastatic LSCC will show cardiac involvement between $1.5 \%$ to $24.0 \%$ of all cases. ${ }^{8}$

Most cases of LSCC cardiac metastasis are detected postmortem, although ante-mortem cases can be detected when symptomatic. ${ }^{9}$ Symptoms of cardiac metastasis are relatively non-specific, but can include fatigue, chest pain, orthopnea, and leg edema. ${ }^{8}$ To date, characterization of metastatic LSCC of the heart has been limited to case reports and case series.

\section{PURPOSE OF REVIEW}

The purpose of this systematic review was to examine the patient demographics, characteristics, management, treatments, complications, and outcomes associated with LSCC cardiac metastases.

\section{METHODS}

This systematic review was completed in 2020 using the Preferred Reporting Systems for Systematic Reviews and MetaAnalysis (PRISMA) guidelines. ${ }^{10}$ Preliminary searches were performed using data from PubMed, Embase, and Cochrane Library comprising studies dated through December 2019. The primary search included the keywords "tongue cancer", "lingual cancer", "buccal cancer", and "metastasis". A secondary search was done using the keywords "cardiac metastasis" and "tongue".

The selected articles were combined to create a composite list of 1,007 studies to review. Studies that included review articles, textbooks, non-human subjects, non-English language, or unrelated topics were excluded. The inclusion criteria utilized in this systematic review are outlined in Figure 1.

\section{STUDY SELECTION AND DATA EXTRACTION}

Each article within the composite list of studies was reviewed for inclusion by two independent authors (CK, TN). The titles and abstracts were screened for information regarding metastatic LSCC presentation, diagnosis, and management. Relevant articles were further examined via full text review and a finalized list was generated for in-depth analysis (Supplemental Table 1). A total of 31 cases of LSCC cardiac metastasis within 28 studies met inclusion criteria and were comprehensively reviewed (Supplemental Table 2).

All 28 selected studies had obtained an Oxford Centre for Evidence-Based Medicine (OCEBM) evidence categorization of Level 4 given their status as either a case report or case series. Relevant patient demographics, symptoms, LSCC history, clinical findings, treatment strategies, complications, and outcomes were collected. It was assumed death had occurred within six months if patients underwent palliative care.

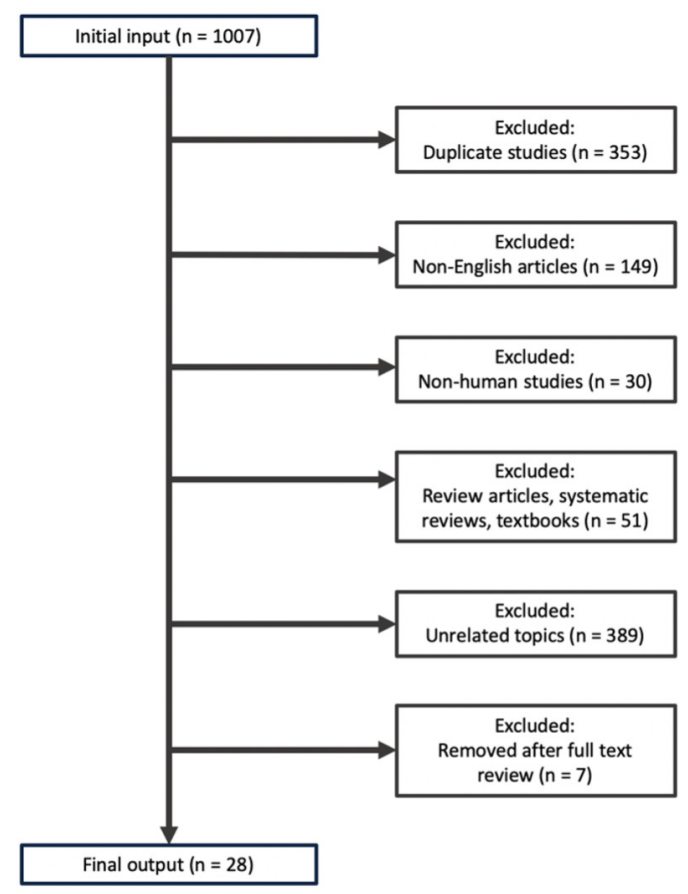

Figure 1. Literature selection criteria. Literature selection methodology was constructed using the Preferred Reporting Items for Systematic Reviews and Meta-Analyses (PRISMA).

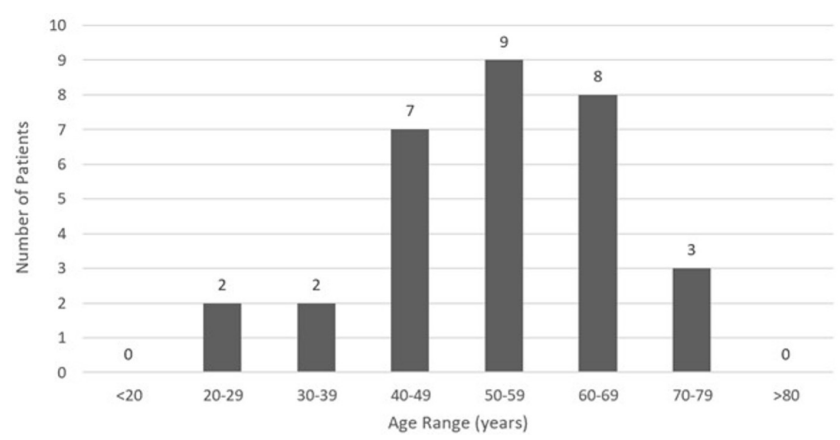

Figure 2. LSCC age distribution by decade of life.

\section{RESULTS \\ SAMPLE DEMOGRAPHICS AND EXPOSURE}

An analysis of demographic characteristics of patients in selected articles included 19 (61.3\%) males and 12 (38.7\%) females with a mean age of $53.6(S D=12.9)$ years ranging from 23.0 - 77.0 years. LSCC cardiac metastasis presented primarily between the ages of 40 - 69 (Figure 2). Average time from primary cancer diagnosis to cardiac metastasis identification was $2.2(\mathrm{SD}=2.6)$ years, ranging from 0.2 - 11.0 years. Ten (32.3\%) patients reported significant tobacco exposure and five (16.1\%) patients admitted to alcohol use. 


\section{PRESENTING SYMPTOMS AND PHYSICAL EXAMINATION}

Chest pain and shortness of breath were the most common causes of initial presentation with nine (29.0\%) cases, followed by five (16.1\%) cases with syncope, four (12.9\%) cases with weight loss, four (12.9\%) cases with fever, four (12.9\%) cases with oral mass, three $(9.7 \%)$ cases with lymphadenopathy (i.e., enlargement of lymph nodes $>$ or $=1$ ), and three $(9.7 \%)$ cases with oral pain. Other symptoms included two (6.5\%) patients with edema, two (6.5\%) patients with hemoptysis (i.e., blood mixed in sputum), and two (6.5\%) patients with palpitations. A complete outline of patient symptomatology is depicted in Figure 3.

The most common physical examination findings included four (12.9\%) patients with hypotension, four (12.9\%) patients with fever, three $(9.7 \%)$ patients with tachycardia, and three (9.7\%) patients with cardiac murmur.

\section{CARDIAC EVALUATION}

Electrocardiogram (ECG) testing was reported in 19 (61.3\%) patients, which found the most common abnormality to be ST-segment elevation in 12 (63.2\%) patients (Supplemental Table 3). Other commonly reported ECG findings included arrhythmia in six (31.6\%) patients, bundle branch block in four $(21.1 \%)$ patients, $t$-wave inversion in four $(21.1 \%)$ patients, and tachycardia in three $(15.8 \%)$ patients. Troponin testing was reported in 31 patients with positive troponin elevations occurring in five (16.1\%) cases.

\section{IMAGING MODALITIES AND FINDINGS}

The most utilized imaging modalities were echocardiogram and computed tomography (CT) both occurring in 24 (77.4\%) cases, followed by positron emission tomography (PET) in 12 (38.7\%) cases, and cardiac magnetic resonance imaging (CMRI) in nine (29.0\%) cases (Figure 4). On echocardiogram, the most common finding was pericardial effusion occurring in seven (29.2\%) cases, followed by six (25.0\%) cases with right ventricular outflow tract obstruction, three (12.5\%) cases with valvular dysfunction, and two (8.3\%) cases with wall motion abnormality (i.e., kinetic alterations in the cardiac wall motion taking place during the cardiac cycle) (Supplemental Table 3 ).

Of the patients with reported valvular dysfunction, two (66.6\%) cases had impaired function of the pulmonic valve and one (33.3\%) case had impaired tricuspid valve function. In the 12 patients who underwent PET scan, extra-cardiac uptake was most reported in the lung with five (41.7\%) reported cases, followed by two $(16.7 \%)$ cases in the bone, two (16.7\%) cases in the liver, and one (8.3\%) case in the muscle. The number of extra-cardiac foci ranged from $0.0-7.0$ sites with an average of $1.8(\mathrm{SD}=1.7)$ sites.

\section{LOCATION OF CARDIAC METASTASIS}

Out of 31 selected cases, 27 disclosed the number of cardiac metastases. Number of distinct cardiac metastases ranged from 1.0 - 4.0, with an average of $1.5(\mathrm{SD}=0.8)$ metastases. Most cases presented with one individual mass in 17 (63.0\%) cases, followed by two masses in 8 (29.6\%) cases, and three or more masses in 2 (7.4\%) cases.

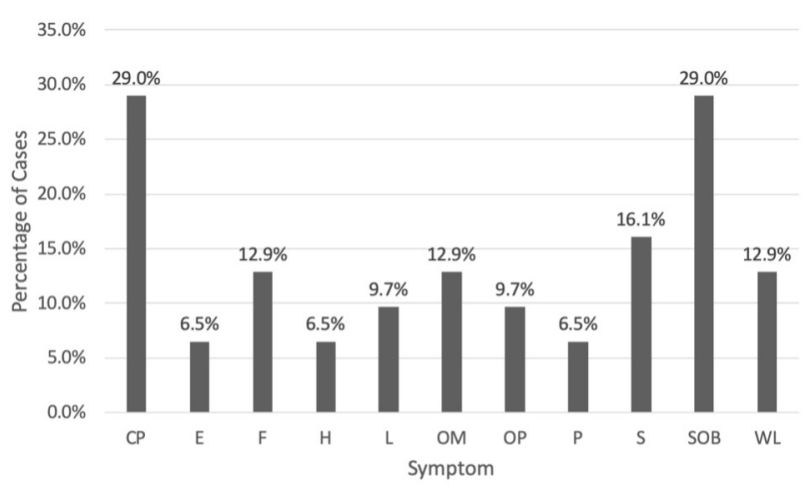

Figure 3: Symptomatology of LCCC Patients diagnosed with cardiac metastasis.

Abbreviations: $\mathrm{CP}=$ chest pain, $\mathrm{E}=$ edema, $\mathrm{F}=$ fever, $\mathrm{H}=$ hemoptysis, $\mathrm{L}=$ lymphadenopathy, $\mathrm{OM}=$ oral mass, $\mathrm{OP}=$ oral pain, $\mathrm{P}=$ palpitations, $\mathrm{S}=$ syncope, $\mathrm{SOB}=$ shortness of breath, $\mathrm{WL}=$ weight loss .

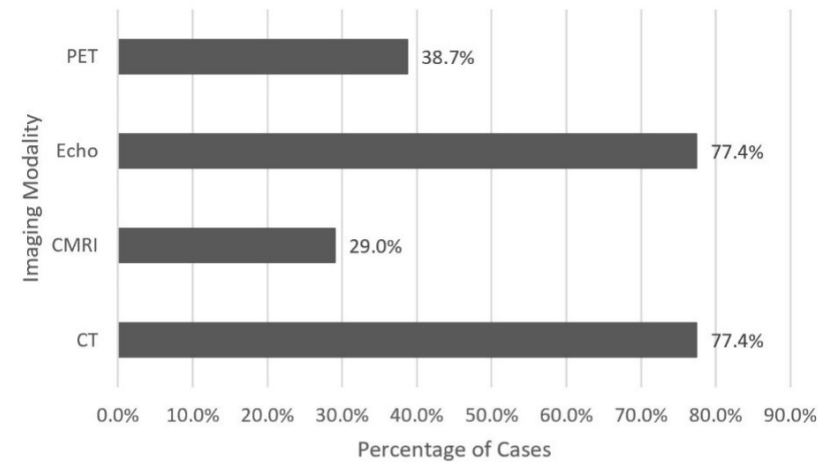

Figure 4: Utilization of diagnostic modalities. Four major imaging modalities were used to assist with the diagnosis of cardiac metastasis from LSCC.

Abbreviations: $\mathrm{CMRI}=$ cardiac magnetic resonance imaging; $\mathrm{CT}=$ computed to mography; Echo = echocardiogram; $\mathrm{PET}$ = positron emission tomography.

The locations of metastases were distinctly specified in 30 of 31 cases. Right-sided metastases were most common with 23 (76.7\%) instances, followed by 15 (50.0\%) instances of left-sided metastases, and 11 (36.7\%) instances of septal metastases. The most common location of metastasis was the right ventricle with 17 (56.7\%) instances, followed by the left ventricle in 13 (43.3\%) instances, interventricular septum in nine $(30.0 \%)$ instances, and right atrium in six (20.0\%) instances. This analysis also revealed eight (26.7\%) patients with pericardial metastasis. Locational distinctions are further defined in Supplemental Table 2 and Supplemental Table 4.

\section{PATIENT MANAGEMENT}

Primary LSCC treatment strategies were discussed in 29 (93.5\%) of 31 total cases. The most frequently reported primary treatment was surgery in 25 (86.2\%) cases, followed closely by radiotherapy in 23 (79.3\%) cases, and chemotherapy in 13 (44.8\%) cases. The most common surgical intervention was neck dissection in eight (32.0\%) cases, followed by partial glossectomy (i.e., removal of tongue tissue) in six 
(24.0\%) cases, and hemi-mandibulectomy (i.e., removal of part of or all of the hemimandible, or one side or half of the mandible) in two (8.0\%) cases.

Treatment strategies for metastatic lesions were described in 22 (71.0\%) of 31 cases which included chemotherapy, surgical intervention, radiotherapy, immunotherapy, and palliative treatment. Given the poor prognosis, the most elected therapy was palliative treatment in 15 (68.2\%) instances. Chemotherapy was the next most common intervention in nine $(40.9 \%)$ instances, followed by surgery in four (18.2\%) instances, radiotherapy in three (13.6\%) instances, and immunotherapy in one (4.5\%) instance.

Of those treated with chemotherapy, the most used agents were cisplatin in three (33.3\%) cases and 5-fluorouracil in three $(33.3 \%)$ cases. Other chemotherapeutics included bleomycin, etoposide, and methotrexate. Of note, immunotherapy with pembrolizumab was utilized in only one (4.5\%) case. Individual treatments are further outlined in Supplemental Table 2.

\section{PATIENT OUTCOMES}

Twenty-two total cases (70.9\%) reported outcome results, of which none showed remission of LSCC cardiac metastasis. Death was reported in 20 (90.9\%) cases with two (9.1\%) cases reporting palliative care and assumed death in less than six months. Of the 14 cases to report death within a known period, 9 (64.3\%) reported death within one month of LSCC cardiac metastasis diagnosis.

Cause of death was listed in 16 cases which included eight (50.0\%) deaths from cardiac metastasis, two (12.5\%) deaths from sepsis, two (12.5\%) deaths from arrhythmia/ sudden cardiac death, one (6.3\%) death from heart failure, one $(6.3 \%)$ death from hemoptysis, one $(6.3 \%)$ death from death in sleep, and one (6.3\%) death from tumor embolism. Four (25.0\%) cases had cardiac-related deaths, while 12 (75.0\%) cases had tumor-specific or non-cardiac deaths.

\section{DISCUSSION}

Primary squamous cell carcinoma (SCC) accounts for more than $90 \%$ of cancer diagnoses within the head and neck region and is the sixth most common cancer overall by incidence. ${ }^{11}$ Classically, LSCC displays a predilection for the elderly male population, ${ }^{12}$ although it can present more aggressively in younger individuals with higher rates of metastasis and mortality. ${ }^{13}$ Recent research also suggests that young Caucasian females are demonstrating an overall increase in disease incidence. ${ }^{7}$ In this study, the majority of patients (51.6\%) were males aged 40-69 years old, consistent with the typical presentation of LSCC.

In addition to age and sex, modifiable factors such as tobacco and alcohol exposure carry significant independent and synergistic risks for LSCC. ${ }^{14,15}$ Exposure to viral infections such as Epstein-Barr virus (EBV) and human papilloma virus (HPV) have also been associated with LSCC. ${ }^{16,17}$ In this systematic review, most cases failed to describe previous history of alcohol or tobacco use and no cases reported previous EBV or HPV exposure.

Cardiac metastasis of LSCC is typically diagnosed postmortem on autopsy due to limited specific clinical manifes- tations. ${ }^{18}$ When diagnosed ante-mortem, patients may present with nonspecific cardiac symptoms such as chest pain, shortness of breath, and palpitations. ${ }^{19}$ In this systematic review, patients commonly demonstrated nonspecific cardiac symptoms such as chest pain, shortness of breath, syncope, and weight loss. Of these symptoms, chest pain and shortness of breath were the most prevalent $(29.0 \%$ of cases), followed by syncope, then weight loss. Common physical exam findings were generally nonspecific (e.g., hypotension, fever, tachycardia, and cardiac murmur) in the selected articles.

Primary SCC originating from the head and neck with cardiac metastasis is extremely rare, as most cardiac neoplasms occur secondarily from areas such as the breast, lung, and esophagus. ${ }^{20}$ When present, cardiac metastasis most frequently occurs in the pericardium, followed by the myocardium, epicardium, endocardium, and intracavitary region. ${ }^{21}$

In this systematic review, right-sided cardiac metastasis was more common than left-sided metastasis, and ventricular involvement was more common than atrial involvement. The examined cases demonstrated a higher incidence of intracardiac tumors compared to pericardial tumors. Possible explanations for these findings relate to the hematogenous spread of squamous cell neoplasms through the coronary arteries, direct contiguous extension, and retrograde lymphatic flow. ${ }^{22}$

Since symptomatic presentations of LSCC cardiac metastasis can be highly variable, imaging studies are needed to assess the extent of cardiac involvement. First-line imaging for cardiac metastasis of LSCC begins with an echocardiogram due to its wide availability and lack of radiation. ${ }^{23}$ When there are no contraindications, contrast-enhanced CT scans are the diagnostic imaging modality of choice, as non-contrast CT scans may fail to identify small myocardial masses. ${ }^{24}$ If further imaging is indicated due to inconclusive CT results, CMRI is considered the most definitive imaging modality for evaluation of myocardial metastasis and delineation of intracardiac tumor thrombi. ${ }^{23}$

Cervical lymph node involvement is a strong prognostic factor when delineating patient outcomes for LSCC. ${ }^{25}$ Fiveyear survival rates for patients with oral SCC lymph node metastasis are low at $25-40 \%$, which contrasts with a $90 \%$ survival rate for individuals without lymph node metastasis. ${ }^{12}$ Metastases to the heart further worsen this prognosis with a median survival of approximately 3.5 months without treatment. ${ }^{26-28}$ Palliative care is typically indicated for LSCC cardiac metastasis patients, as most cases present with poorly prognostic advanced cardiac SCC metastasis. ${ }^{26}$

During this review, no example of remission or significant survival was demonstrated in patients with cardiac metastasis of LSCC. Many cases resulted in cardiac-related death within 30 days of cardiac metastasis presentation and five deaths occurred upon initial admission for metastatic evaluation. These findings suggest that palliation may be the most appropriate treatment strategy for patients with LSCC cardiac metastasis given the poor prognosis with current treatment strategies. 


\section{REVIEW LIMITATIONS}

This systematic review had several limitations. First, only 31 cases of cardiac metastasis from LSCC met inclusion criteria which limits the power of this study. Second, LSCC cardiac metastasis may have been underreported in the medical literature due to missed diagnoses from lack of symptomatology or post-mortem follow-up. Third, the results of this study may not be completely representative of all documented cases of LSCC cardiac metastasis due to the omission of many non-English case reports and case series.

\section{CONCLUSIONS}

Cardiac metastasis from primary LSCC demonstrates a dangerous, uncommon presentation of malignancy. Clinical suspicion for LSCC cardiac metastasis should arise in patients with new onset chest pain and shortness of breath in the setting of prior diagnosis of LSCC. Prior tobacco and alcohol use should generate additional diagnostic speculation in these patients.
In the setting of previously known disease, advanced imaging such as echocardiogram, CT, and CMRI may prove useful for identification of disease progression. LSCC cardiac metastases typically favor the right and left ventricles, but are not exclusive to these sites. Due to the poor prognostic implications of LSCC cardiac metastasis, myocardial biopsy is unlikely to alter patient management and palliative discussions should be considered.

\section{CONFLICT OF INTEREST}

None

FINANCIAL SUPPORT

None

Submitted: March 26, 2021 EDT, Accepted: August 05, 2021 EDT 


\section{REFERENCES}

1. Rodrigues VC, Moss SM, Tuomainen H. Oral cancer in the UK: To screen or not to screen. Oral Oncol. 1998;34(6):454-465. doi:10.1016/s1368-8375(98)0005 $\underline{2-9}$

2. Sano D, Myers JN. Metastasis of squamous cell carcinoma of the oral tongue. Cancer Metastasis Rev. 2007;26(3-4):645-662. doi:10.1007/s10555-007-908 2-y

3. Irani S. Distant metastasis from oral cancer: A review and molecular biologic aspects. J Int Soc Prev Community Dent. 2016;6(4):265-271. doi:10.4103/223 $\underline{1-0762.186805}$

4. Jemal A, Clegg LX, Ward E, et al. Annual report to the nation on the status of cancer, 1975-2001, with a special feature regarding survival. Cancer. 2004;101(1):3-27. doi:10.1002/cncr.20288

5. Santos HB, dos Santos T, Paz A, et al. Clinical findings and risk factors to oral squamous cell carcinoma in young patients: A 12-year retrospective analysis. Med Oral Patol Oral y Cir Bucal. 2016;21(2):e151-156. doi:10.4317/medoral.20770

6. Llewellyn CD, Johnson NW, Warnakulasuriya KA. Risk factors for squamous cell carcinoma of the oral cavity in young people - a comprehensive literature review. Oral Oncol. 2001;37(5):401-418. doi:10.1016/s 1368-8375(00)00135-4

7. Ng JH, Iyer NG, Tan M-H, Edgren G. Changing epidemiology of oral squamous cell carcinoma of the tongue: A global study. Head Neck. 2017;39(2):297-304. doi:10.1002/hed.24589

8. Pattni N, Rennie A, Hall T, Norman A. Cardiac metastasis of oral squamous cell carcinoma. BMJ Case Rep. 2015;2015:bcr2015211275. doi:10.1136/bcr-201 5-211275

9. Kim JK, Sindhu K, Bakst RL. Cardiac metastasis in a patient with head and neck cancer: A case report and review of the literature. Case Rep Otolaryngol. 2019;2019:1-8. doi:10.1155/2019/9581259

10. Moher D, Liberati A, Tetzlaff J, Altman DG, for the PRISMA Group. Preferred reporting items for systematic reviews and meta-analyses: The PRISMA statement. BMJ. 2009;339:b2535. doi:10.1136/bmj.b2 535

11. Mendelsohn AC, Gray JE, Howley A, et al. The Molecular Basis of Cancer. Philadelphia, PA: Saunders; 2015.
12. Noguti J, De Moura CF, De Jesus GP, et al. Metastasis from oral cancer: An overview. Cancer Genomics and Proteomics. 2012;9(5):329-336.

13. Jeon JH, Kim MG, Park JY, et al. Analysis of the outcome of young age tongue squamous cell carcinoma. Maxillofac Plast Reconstr Surg. 2017;39(1):41. doi:10.1186/s40902-017-0139-8

14. Bachar G, Hod R, Goldstein DP, et al. Outcome of oral tongue squamous cell carcinoma in patients with and without known risk factors. Oral Oncol. 2011;47(1):45-50. doi:10.1016/j.oraloncology.2010.1 $\underline{1.003}$

15. Subapriya R, Thangavelu A, Mathavan B, Ramachandran CR, Nagini S. Assessment of risk factors for oral squamous cell carcinoma in Chidambaram, southern India: A case-control study. Eur J Cancer Prev. 2007;16(3):251-256. doi:10.1097/0 1.cej.0000228402.53106.9e

16. Guidry JT, Birdwell CE, Scott RS. Epstein-Barr virus in the pathogenesis of oral cancers. Oral Dis. 2018;24(4):497-508. doi:10.1111/odi.12656

17. Ragin CC, Modugno F, Gollin SM. The epidemiology and risk factors of head and neck cancer: A focus on human papillomavirus. J Dent Res. 2007;86(2):104-114. doi:10.1177/15440591070860020 $\underline{2}$

18. Delabie P, Evrard D, Zouhry I, et al. Squamous cell carcinoma of the tongue with cardiac metastasis on 18F-FDG PET/CT: A case report and literature review. Medicine (Baltimore). 2021;100(15):e25529. doi:10.109 7/md.0000000000025529

19. Malekzadeh S, Platon A, Poletti PA. Cardiac metastasis of tongue squamous cell carcinoma complicated by pulmonary embolism. Medicine (Baltimore). 2017;96(28):e7462. doi:10.1097/md.0000 000000007462

20. Tandon V, Kethireddy N, Balakumaran K, Kim AS. Metastatic squamous cell carcinoma to the heart: An unusual cause of ST elevation-a case report. Eur Heart J Case Rep. 2019;3(2):ytz029. doi:10.1093/ehjcr/ ytz029

21. Scott RW, Garvin CF. Tumors of the heart and pericardium. Am Heart J. 1939;17(4):431-436. doi:10.1 016/s0002-8703(39)90593-4 
22. Werbel GB, Skom JH, Mehlman D, Michaelis LL. Metastatic squamous cell carcinoma to the heart. Unusual cause of angina decubitus and cardiac murmur. Chest. 1985;88(3):468-469. doi:10.1378/ches t.88.3.468

23. Lichtenberger JP, Reynolds DA, Keung J, Keung E, Carter BW. Metastasis to the heart: A radiologic approach to diagnosis with pathologic correlation. Am J Roentgenol. 2016;207(4):764-772. doi:10.2214/aj $\underline{\text { r.16.16148 }}$

24. Zitzelsberger T, Eigentler TK, Krumm P, et al. Imaging characteristics of cardiac metastases in patients with malignant melanoma. Cancer Imaging. 2017;17(1):19. doi:10.1186/s40644-017-0122-8

25. Leemans CR, Tiwari R, Nauta J, Van der Waal I, Snow GB. Regional lymph node involvement and its significance in the development of distant metastases in head and neck carcinoma. Cancer.

1993;71(2):452-456. doi:10.1002/1097-0142(1993011 5) $71: 2$

26. Reynen K, Köckeritz U, Strasser RH. Metastases to the heart. Ann Oncol. 2004;15(3):375-381. doi:10.109 3/annonc/mdh086

27. Takenaka S, Hashimoto N, Araki N, et al. Eleven cases of cardiac metastases from soft-tissue sarcomas. Jpn J Clin Oncol. 2011;41(4):514-518. doi:1 $\underline{0.1093 / \mathrm{jico} / \mathrm{hyq} 246}$

28. Fotouhi Ghiam A, Dawson LA, Abuzeid W, et al. Role of palliative radiotherapy in the management of mural cardiac metastases: Who, when and how to treat? A case series of 10 patients. Cancer Med. 2016;5(6):989-996. doi:10.1002/cam4.619

29. Nagata S, Ota K, Nagata M, Shinohara M. Cardiac metastasis of head and neck squamous cell carcinoma. Int J Oral Maxillofac Surg. 2012;41(12):1458-1462. doi:10.1016/i.ijom.2012.07.01 7

30. Onwuchekwa J, Banchs J. Early cardiac metastasis from squamous cell carcinoma of the tongue in 2 patients. Tex Heart Inst J. 2012;39(4):565-567.

31. Browning CM, Craft JF, Renker M, Joseph Schoepf $\mathrm{U}$, Baumann S. Squamous cell carcinoma of the tongue with metastasis to the right ventricle. Am J Med Sci. 2015;349(5):461-462. doi:10.1097/maj.00000 00000000411

32. McKeag N, Hall V, Johnston N, et al. Cardiac metastasis from a squamous cell carcinoma of the tongue in the absence of local recurrence. Ulster Med J. 2013;82(3):193-194.
33. Hans S, Chauvet D, Sadoughi B, Brasnu DF. Cardiac metastasis after squamous cell carcinoma of the base of tongue. Am J Otolaryngol. 2009;30(3):206-208. doi:10.1016/j.amjoto.2008.03.00 $\underline{8}$

34. Kumar D, Mankame P, Sabnis G, Nabar A. A case report: metastatic complete heart block. Eur Heart J Case Rep. 2018;2(4):yty131. doi:10.1093/ehjcr/yty131

35. Nanda A, Khouzam RN, Jefferies J, Moon M, Makan M. Right heart mass in transit with a hemorrhagic pericardial effusion: A diagnostic dilemma. Cureus. 2019;11(2):e4009. doi:10.7759/cure $\underline{\text { us.4009 }}$

36. Werbel GB, Skom JH, Mehlman D, Michaelis LL. Metastatic squamous cell carcinoma to the heart. Chest. 1985;88(3):468-469. doi:10.1378/chest.88.3.46 $\underline{8}$

37. Puranik AD, Purandare NC, Sawant S, et al. Asymptomatic myocardial metastasis from cancers of upper aero-digestive tract detected on FDG PET/CT: A series of 4 cases. Cancer Imaging. 2014;14(1):16. do $\mathrm{i}: 10.1186 / 1470-7330-14-16$

38. Makhija Z, Deshpande R, Desai J. Unusual tumours of the heart: Diagnostic and prognostic implications. J Cardiothorac Surg. 2009;4(1). doi:10.11 86/1749-8090-4-4

39. Wadler S, Muller R, Spigelman MK, Biller H. Fulminant disseminated carcinomatosis arising from squamous cell carcinoma of the tongue. Am J Med. 1985;78(1):149-152. doi:10.1016/0002-9343(85)9047 6-0

40. Shafiq A, Samad F, Roberts E, Tajik AJ. Squamous cell carcinoma of the tongue with metastasis to the myocardium: A rare occurrence. J Am Coll Cardiol. 2019;73(9):2258. doi:10.1016/s0735-1097(19)32864-5

41. Dredla B, Siegel J, Jaeckle K. BM-12: Cerebral infarction secondary to pulmonary vein compression and left atrial appendage tumor infiltration as the presenting sign of metastatic squamous cell carcinoma of the base of the tongue. NeuroOncol. 2014;16(suppl 5):v34. doi:10.1093/neuonc/nou240.12

42. Yadav NU, Gupta D, Baum MS, Roistacher N, Steingart RM. Cardiac metastases from head and neck cancer mimicking a myocardial infarction. J Oral Maxillofac Surg. 2014;72(8):1627-1635. doi:10.1016/j.j oms.2014.02.015

43. Zatuchni J, Burris A, Vejviboonsom P, Voci G. Metastatic epidermoid cardiac tumor manifested by persistent ST segment elevation. Am Heart J. 1981;101(5):674-675. doi:10.1016/0002-8703(81)9023 $\underline{8-6}$ 
44. Shafiq A, Samad F, Roberts E, Levin J, Nawaz U, Tajik AJ. Squamous cell carcinoma of the tongue with metastasis to myocardium: Report of a case and literature review. Case Rep Cardiol. 2019;2019:1-6. do i: $10.1155 / 2019 / 1649580$

45. Kim JK, Sindhu K, Bakst RL. Cardiac metastasis in a patient with head and neck cancer: A case report and review of the literature. Case Rep Otolaryngol. 2019;2019:1-8. doi:10.1155/2019/9581259

46. Demir V, Ede H, Hidayet S, Turan Y. Right ventricular metastasis producing electrocardiographic changes mimicking acute ST elevation myocardial infarction: a case of misdiagnosis. Am J Cardiol. 2018;121(8):e131. doi:1 $\underline{0.1016 / j . a m j c a r d .2018 .03 .299}$

47. Chua S, Liu WH, Lee WC. Isolated huge right ventricular tumor: Cardiac metastasis of tongue cancer. Korean J Intern Med. 2017;32(6):1119-1120. do i:10.3904/kjim.2016.143

48. Duband S, Paysant F, Scolan V, Forest F, Péoc'h M. Sudden death due to myocardial metastasis of lingual squamous cell carcinoma. Cardiovasc Pathol. 2011;20(4):242-243. doi:10.1016/i.carpath.2010.07.00 $\underline{2}$

49. Ito T, Ishikawa N, Negishi T, Ohno K. Cardiac metastasis of tongue cancer may cause sudden death. Auris Nasus Larynx. 2008;35(3):423-425. doi:10.1016/ j.anl.2007.04.017
50. Rivkin A, Meara JG, Li KK, Potter C, Wenokur R. Squamous cell metastasis from the tongue to the myocardium presenting as pericardial effusion. Otolaryngol Head Neck Surg. 1999;120(4):593-595. do i:10.1053/hn.1999.v120.a84489

51. Matsuyama M, Ito M, Baba S. Lingual cancer with myocardial metastasis. Ann Otol Rhinol Laryngol. 1963;72(1):56-61. doi:10.1177/000348946307200105

52. Cabot RC, Castleman B, McNeely BU, Kranes A, Scully RE. Case records of the Massachusetts General Hospital. Weekly clinicopathological exercises. Case 8-1971. N Engl J Med. 1971;284(8):435-442. doi:10.10 56/nejm197102252840809

53. Reddy G, Ahmed MI, Lloyd SG, Brott BC, Bittner V. Left anterior descending coronary artery occlusion secondary to metastatic squamous cell carcinoma presenting as ST-segment-elevation myocardial infarction. Circulation. 2014;129(24):e652-653. doi:1 0.1161/circulationaha.114.009157

54. Ewald FW, Scherff AH. A 60-year-old man with a malignant tumor of the upper airway and unexplained respiratory failure. Chest. 1997;111(1):239-241. doi:10.1378/chest.111.1.239 


\section{SUPPLEMENTARY TABLES}


Supplemental Table 1. Level of evidence and conclusion of studies.

\begin{tabular}{|c|c|c|c|c|c|}
\hline Authors & $\begin{array}{c}\text { Study } \\
\text { Year }\end{array}$ & $\begin{array}{c}\text { LOE } \\
(1 a-5)\end{array}$ & $\begin{array}{l}\text { Study } \\
\text { Design }\end{array}$ & Subjects & Authors' Conclusions \\
\hline Tandon $^{20}$ & 2019 & 4 & CR & 1 & $\begin{array}{l}\text { Patients with current malignancies in addition to } \\
\text { cardiac symptoms and/or ECG changes should warrant } \\
\text { investigation for possible cardiac metastasis. Different } \\
\text { imaging modalities such as CMRI, PET-CT, and } \\
\text { echocardiography play an important role in diagnosis } \\
\text { and management. }\end{array}$ \\
\hline Nagata 29 & 2012 & 4 & $\mathrm{CR}$ & 1 & $\begin{array}{l}\text { Cardiac metastasis from LSCC is typically a difficult } \\
\text { diagnosis due to the lack of clinical findings in the early } \\
\text { stages. However, as the metastases become more } \\
\text { advanced, clinical signs may occur, resulting in a variety } \\
\text { of cardiac pathologies. Many of the cardiac sequelae } \\
\text { result in ECG changes, emphasizing the importance of } \\
\text { ECG testing in these patients. }\end{array}$ \\
\hline Onwuchekwa ${ }^{30}$ & 2012 & 4 & CS & 2 & $\begin{array}{l}\text { These cases show the importance of evaluating the } \\
\text { heart with echocardiography to assess for cardiac } \\
\text { metastasis in patients with head and neck cancer and } \\
\text { confirmed metastatic disease. }\end{array}$ \\
\hline Browning 31 & 2015 & 4 & $\mathrm{CR}$ & 1 & $\begin{array}{l}\text { It may be necessary to evaluate patients with lingual } \\
\text { malignancies with imaging to rule out metastases. } \\
\text { Lingual squamous cell carcinoma metastases are } \\
\text { commonly asymptomatic, and thus, imaging is } \\
\text { important in establishing the diagnosis. }\end{array}$ \\
\hline McKeag 32 & 2013 & 4 & CR & 1 & $\begin{array}{l}\text { This case shows that cardiac metastasis from LSCC can } \\
\text { present without symptoms or characteristic metastasis } \\
\text { examination findings such as lymphadenopathy. }\end{array}$ \\
\hline Hans $^{33}$ & 2009 & 4 & $\mathrm{CR}$ & 1 & $\begin{array}{l}\text { Clinicians may consider the potential for cardiac } \\
\text { metastases in patients with a history of head and neck } \\
\text { malignancies who display new-onset cardiovascular } \\
\text { symptoms. These patients typically have a very poor } \\
\text { prognosis. }\end{array}$ \\
\hline Kumar ${ }^{34}$ & 2018 & 4 & $\mathrm{CR}$ & 1 & $\begin{array}{l}\text { Clinicians should consider cardiac metastasis and } \\
\text { hypercalcemia-induced rhythm disturbances in patients } \\
\text { with a history of LSCC malignancy or current LSCC } \\
\text { malignancy and concurrent ECG changes. It may be } \\
\text { necessary to check calcium levels and treat the patient } \\
\text { if levels are abnormal. }\end{array}$ \\
\hline Nanda 35 & 2019 & 4 & $\mathrm{CR}$ & 1 & $\begin{array}{l}\text { This case shows the importance of an initial } \\
\text { echocardiogram in addition to the integration of PET } \\
\text { and CT scans to detect LSCC cardiac metastasis. }\end{array}$ \\
\hline Werbel ${ }^{36}$ & 1985 & 4 & $\mathrm{CR}$ & 1 & $\begin{array}{l}\text { This case demonstrates the importance of using } \\
\text { echocardiography in patients with LSCC and atypical } \\
\text { angina and/or a new heart murmur. Echocardiography is } \\
\text { a good initial step to look for cardiac metastases. }\end{array}$ \\
\hline Puranik ${ }^{37}$ & 2014 & 4 & CS & 2 & $\begin{array}{l}\text { In asymptomatic patients with a history of cancer, } \\
\text { whole body dual imaging with PET-CT can show } \\
\text { undiagnosed metastatic sites. }\end{array}$ \\
\hline Makhija38 & 2009 & 4 & $\mathrm{CR}$ & 1 & $\begin{array}{l}\text { This case report stresses the lack of appropriate } \\
\text { screening protocols for patients with LSCC and possible } \\
\text { cardiac metastases. The report recommends a } \\
\text { transesophageal echocardiogram as the best initial } \\
\text { screen, as it is a sensitive test. }\end{array}$ \\
\hline Wadler 39 & 1985 & 4 & $\mathrm{CR}$ & 1 & $\begin{array}{l}\text { This case report emphasizes that there are many other } \\
\text { factors besides morphology and anatomic extent that } \\
\text { can be used to determine LSCC prognosis. }\end{array}$ \\
\hline Shafiq ${ }^{40}$ & 2019 & 4 & $\mathrm{CR}$ & 1 & $\begin{array}{l}\text { This case report shows that the lack of symptoms in } \\
\text { cardiac metastasis from LSCC can result in delayed } \\
\text { cardiac imaging and subsequently delayed diagnosis. }\end{array}$ \\
\hline Dredla ${ }^{41}$ & 2014 & 4 & $\mathrm{CR}$ & 1 & $\begin{array}{l}\text { Patients with a history of cancer who have a } \\
\text { cerebrovascular accident should have cardiac imaging } \\
\text { to rule out a cardiac cause, such as cardiac metastases. }\end{array}$ \\
\hline
\end{tabular}




\begin{tabular}{|c|c|c|c|c|c|}
\hline Yadav $^{42}$ & 2014 & 4 & $\mathrm{CR}$ & 1 & $\begin{array}{l}\text { This case highlights the importance of an ECG } \\
\text { evaluation in patients with a cancer diagnosis. This can } \\
\text { provide diagnostic clues for potential cardiac } \\
\text { metastases. Diagnostic confirmation can be done using } \\
\text { multiple imaging modalities, such as echocardiography, } \\
\text { CT scan, and CMRI. }\end{array}$ \\
\hline Zatuchni ${ }^{43}$ & 1981 & 4 & CS & 2 & $\begin{array}{l}\text { LSCC cardiac metastasis can result in myocardial or } \\
\text { pericardial injury, shown by ST-elevations on ECG. ST- } \\
\text { elevation may be a potential sign of cardiac metastasis. }\end{array}$ \\
\hline Shafiq ${ }^{44}$ & 2019 & 4 & $\mathrm{CR}$ & 1 & $\begin{array}{l}\text { This case emphasizes the importance of the clinician } \\
\text { maintaining a high index of suspicion to identify patients } \\
\text { with metastatic LSCC. A high risk patient may need } \\
\text { surveillance imaging with echocardiography, CMRI, } \\
\text { and/or PET-CT. }\end{array}$ \\
\hline $\mathrm{Kim}^{45}$ & 2019 & 4 & $\mathrm{CR}$ & 1 & $\begin{array}{l}\text { LSCC patients with cardiac symptoms may benefit from } \\
\text { a multimodal approach consisting of PET-CT, CMRI, } \\
\text { echocardiography, and ECG. These imaging modalities } \\
\text { are used to confirm the diagnosis and establish the } \\
\text { location and extent of disease, which can guide } \\
\text { management. }\end{array}$ \\
\hline Demir 46 & 2018 & 4 & $\mathrm{CR}$ & 1 & $\begin{array}{l}\text { This case shows the importance of keeping myocardial } \\
\text { metastases on the differential diagnosis when patients } \\
\text { with known malignancies present with ECG changes. } \\
\text { Cardiac metastases can sometimes present like an } \\
\text { acute myocardial infarction on ECG testing. }\end{array}$ \\
\hline Chua $^{47}$ & 2017 & 4 & $\mathrm{CR}$ & 1 & $\begin{array}{l}\text { LSCC is more common in Asian countries. It is always } \\
\text { important to consider metastasis of LSCC to the heart } \\
\text { and other organs, especially if patients with known } \\
\text { LSCC present with cardiac symptoms. }\end{array}$ \\
\hline Duband 48 & 2011 & 4 & $\mathrm{CR}$ & 1 & $\begin{array}{l}\text { Clinicians may consider an initial cardiac evaluation and } \\
\text { serial follow-up ECGs in patients with SCC of the base } \\
\text { of the tongue. }\end{array}$ \\
\hline Ito 49 & 2007 & 4 & $\mathrm{CR}$ & 1 & $\begin{array}{l}\text { Sudden death in patients with LSCC should prompt } \\
\text { clinicians to consider the potential of cardiac } \\
\text { metastases. }\end{array}$ \\
\hline Rivkin 50 & 1999 & 4 & $\mathrm{CR}$ & 1 & $\begin{array}{l}\text { Patients with cancer who develop new cardiac } \\
\text { symptoms should prompt the clinician to evaluate for } \\
\text { potential cardiac metastases. Evaluation should consist } \\
\text { of echocardiography and/or CMRI. Treatments are } \\
\text { typically only palliative, as cardiac metastases possess a } \\
\text { poor prognosis. }\end{array}$ \\
\hline Matsuyama 51 & 1963 & 4 & $\mathrm{CR}$ & 1 & $\begin{array}{l}\text { This case reports a rare finding of widespread LSCC } \\
\text { metastasis with cardiac metastases isolated to the } \\
\text { myocardium. This is a rare finding since most } \\
\text { metastases affect the pericardium. }\end{array}$ \\
\hline Malekzadeh ${ }^{19}$ & 2017 & 4 & $\mathrm{CR}$ & 1 & $\begin{array}{l}\text { Patients with a history of head and neck malignancy } \\
\text { who present with cardiac symptoms may prompt the } \\
\text { clinician to evaluate for cardiac metastases. }\end{array}$ \\
\hline Cabot $^{52}$ & 1971 & 4 & $\mathrm{CR}$ & 1 & $\begin{array}{l}\text { There are often no clinical signs of primary LSCC or } \\
\text { metastatic LSCC to the heart, making the ante-mortem } \\
\text { diagnosis very difficult. }\end{array}$ \\
\hline Reddy ${ }^{53}$ & 2014 & 4 & $\mathrm{CR}$ & 1 & $\begin{array}{l}\text { Management of tumor-induced acute coronary } \\
\text { occlusion is similar to acute coronary syndrome } \\
\text { occlusion, utilizing coronary angiography and } \\
\text { percutaneous coronary intervention. }\end{array}$ \\
\hline Ewald $^{54}$ & 1997 & 4 & $\mathrm{CR}$ & 1 & $\begin{array}{l}\text { Patients with a history of malignancy and unexplained } \\
\text { arrhythmias or ECG changes may prompt the clinician } \\
\text { to consider cardiac metastases on the differential } \\
\text { diagnosis. Cardiac metastasis may present similarly to } \\
\text { many types of cardiac pathology. }\end{array}$ \\
\hline
\end{tabular}

Abbreviations: $\mathrm{CMRI}=$ cardiac magnetic resonance imaging; $\mathrm{CR}=$ case report $\mathrm{CS}=$ case series $\mathrm{CT}=$ computed tomography; ECG = electrocardiogram; $\mathrm{LSCC}=$ lingual squamous cell carcinoma; PET = positron emission tomography; PET-CT = positron emission tomography-computed tomography; SCC = squamous cell carcinoma. 
Supplemental Table 2. Detailed Patient Information.

\begin{tabular}{|c|c|c|c|c|c|c|c|}
\hline $\begin{array}{l}\text { Age/ } \\
\text { Sex }\end{array}$ & $\begin{array}{l}\text { Primary } \\
\text { Location }\end{array}$ & Signs \& Symptoms & $\begin{array}{l}\text { Metastasis } \\
\text { Locations }\end{array}$ & $\begin{array}{l}\text { First } \\
\text { Identifying } \\
\text { Imaging }\end{array}$ & Primary Treatment & $\begin{array}{l}\text { Metastasis } \\
\text { Treatment }\end{array}$ & Outcomes \\
\hline M59 & $\begin{array}{l}\text { Right tongue } \\
\text { mass }\end{array}$ & Fever & LA \& pericardium & CT \& Echo & Partial glossectomy, right RND, CTX & Cardiac surgery & $\begin{array}{c}\text { Death } 3 \text { weeks after } \\
\text { surgery }\end{array}$ \\
\hline $\mathrm{F} 45$ & Tongue & Syncope \& dyspnea & RV, LV, IVS & $\begin{array}{l}\text { CTA \& } \\
\text { Echo }\end{array}$ & Partial right glossectomy, RND, RT. & $\mathrm{RT}$ (brain) & NR \\
\hline F 36 & Tongue & Palpitations \& SOB & LV & CT \& Echo & $\begin{array}{l}\text { CTX-RT, partial left glossectomy, and } \\
\text { left neck LN dissection }\end{array}$ & RT & $\begin{array}{l}\text { Death } 2 \text { months } \\
\text { after }\end{array}$ \\
\hline M 50 & $\begin{array}{l}\text { Base of } \\
\text { tongue }\end{array}$ & $\begin{array}{c}\text { Odynophagia, otalgia, } \\
\text { dysphonia, WL, tongue and } \\
\text { neck pain }\end{array}$ & Apex of RV & PET-CT & $\begin{array}{c}2 \text { months radiation, total glossectomy } \\
\& \text { bilateral RND }\end{array}$ & None & NR \\
\hline M77 & NR & Recurrent syncope & $\begin{array}{l}\text { RA \& RV infiltration } \\
\text { of myocardium }\end{array}$ & Echo & None & None & $\begin{array}{c}\text { Death } 28 \text { days after } \\
\text { diagnosis }\end{array}$ \\
\hline M54 & Tongue base & $\begin{array}{c}\text { Dyspnea, LE edema, \& } \\
\text { hemoptysis }\end{array}$ & RV & CT \& Echo & Glossectomy, left RND, cisplatin, 5-FU & None & Death \\
\hline $\mathrm{F} 23$ & Tongue & $\begin{array}{l}\text { CP, Right arm paresthesias, } \\
\text { cough, SOB }\end{array}$ & $\begin{array}{l}\text { LV \& RV infiltration } \\
\text { of myocardium }\end{array}$ & Echo & Surgical resection with clear margins & None & NR \\
\hline M 28 & Tongue & Recurrent syncope & RA, LV, IVS & Echo & $\begin{array}{l}\text { Hemimandibulectomy \& post- } \\
\text { operative RT }\end{array}$ & $\begin{array}{l}\text { Pacemaker } \\
\text { implantation }\end{array}$ & $\begin{array}{l}\text { Death } 5 \text { days after } \\
\text { pacemaker } \\
\text { placement }\end{array}$ \\
\hline M47 & Tongue & $\begin{array}{l}\text { Dizziness, SOB, chest } \\
\text { tightness, night sweats }\end{array}$ & $\begin{array}{l}\text { RA, RV, pulmonary } \\
\text { artery }\end{array}$ & CT chest & Surgical excision with CTX-RT & None & $\begin{array}{l}\text { Patient lost to } \\
\text { follow-up }\end{array}$ \\
\hline F 61 & $\begin{array}{l}\text { Base of } \\
\text { tongue }\end{array}$ & $\mathrm{CP}$, palpitations & RA \& pericardium & Echo & $\begin{array}{l}\text { Hemiglossectomy with excisional } \\
\text { biopsy of digastric LN. Neck RT }\end{array}$ & None & $\begin{array}{c}\text { Death } 7 \text { weeks after } \\
\text { cardiac diagnosis }\end{array}$ \\
\hline F 32 & $\begin{array}{l}\text { Right. lateral } \\
\text { tongue }\end{array}$ & Nasal swelling & LV \& IVS & $\begin{array}{l}\text { PET-CT } \\
\text { scan }\end{array}$ & $\begin{array}{c}\text { Wide excision \& right lateral neck } \\
\text { dissection }\end{array}$ & CTX & Follow-up CT stable \\
\hline M 46 & $\begin{array}{c}\text { Right } \\
\text { vallecula }\end{array}$ & N/A (Follow-up) & $\mathrm{RV}$ & Endoscopy & CTX-RT & CTX & $\begin{array}{l}\text { Patient lost to } \\
\text { follow-up }\end{array}$ \\
\hline F 66 & Tongue & Anginal symptoms & $\mathrm{RV}$ & $\begin{array}{l}\text { Coronary } \\
\text { angiogram }\end{array}$ & Radical resection & None & NR \\
\hline M 57 & $\begin{array}{l}\text { Anterior } \\
\text { tongue }\end{array}$ & Fever, dyspnea & $\begin{array}{l}\text { Epicardium, } \\
\text { myocardium, } \\
\text { endocardium }\end{array}$ & Echo & Partial glossectomy & CTX & $\begin{array}{c}\text { Death } 14 \text { days after } \\
\text { admission from } \\
\text { sepsis }\end{array}$ \\
\hline M43 & Tongue & N/A (Follow-up) & Apex of LV \& RV & CT \& Echo & CTX-RT & CTX & $\begin{array}{c}\text { Death due to cardiac } \\
\text { metastasis }\end{array}$ \\
\hline
\end{tabular}




\begin{tabular}{|c|c|c|c|c|c|c|c|}
\hline M 61 & $\begin{array}{l}\text { Left tongue } \\
\text { base }\end{array}$ & Cerebral infarction symptoms & $\begin{array}{l}\text { LAA and pulmonary } \\
\text { vein }\end{array}$ & CT \& Echo & CTX-RT & None & NR \\
\hline M76 & Tongue & Pneumonia & $\mathrm{RV}, \mathrm{LV}$ & CT chest & $\begin{array}{l}\text { Partial glossectomy, multiple neck } \\
\text { dissection, CTX }\end{array}$ & Palliative care & Died in one month \\
\hline M 61 & Tongue & CP, dyspnea & $\begin{array}{l}\text { IVS and } \\
\text { pericardium }\end{array}$ & $\begin{array}{c}99 \mathrm{mTC} \\
\text { scan }\end{array}$ & RAD & None & Death \\
\hline M62 & Tongue & Malaise & $\begin{array}{l}\text { Diffuse } \\
\text { myocardium }\end{array}$ & $\begin{array}{c}99 \mathrm{mTC} \\
\text { scan }\end{array}$ & NS & None & Death \\
\hline M43 & Right tongue & N/A (Follow-up) & RV, LV & CT chest & $\begin{array}{l}\text { Right neck dissection \& tongue } \\
\text { resection, free flap reconstruction, } \\
\text { CTX-RT }\end{array}$ & CTX-RT & Death \\
\hline $\mathrm{F} 46$ & $\begin{array}{l}\text { Left lateral } \\
\text { tongue }\end{array}$ & Left arm, ear, and throat pain & $\mathrm{LV}$, pericardium & CT & $\begin{array}{l}\text { Hemiglossectomy, bilateral neck } \\
\text { dissection, CTX-RT }\end{array}$ & CTX-RT & NR \\
\hline M59 & Tongue & Chest discomfort & $\mathrm{RV}$ & Echo & Resection, RT & None & Death \\
\hline M63 & Tongue & Dyspnea & $\mathrm{RV}$ & Echo & Resection and reconstruction & None & NR \\
\hline $\mathrm{F} 57$ & Tongue & Death & RA, AV sulcus & Autopsy & $\begin{array}{l}\text { Hemiglossectomy, bilateral cervical } \\
\text { lymphadenectomy, CTX-RT }\end{array}$ & None & Death \\
\hline M 66 & $\begin{array}{l}\text { Right tongue } \\
\text { into } \\
\text { oropharynx }\end{array}$ & Death & LV, IVS & Autopsy & $\begin{array}{l}\text { Total glossolaryngectomy and } \\
\text { dissection LN bilaterally }\end{array}$ & None & Death \\
\hline M 57 & $\begin{array}{l}\text { Right tongue } \\
\text { base }\end{array}$ & Lower extremity edema & $\mathrm{RV}$ & $\begin{array}{l}\text { Echo, ECG, } \\
\text { CMRI, CT }\end{array}$ & $\begin{array}{c}\text { Local excision with post-operative RT } \\
\text { to lesion and neck }\end{array}$ & CTX & Death \\
\hline $\mathrm{F} 48$ & $\begin{array}{l}\text { Anterior } \\
\text { tongue }\end{array}$ & $\begin{array}{l}\text { CP, dyspnea, hemoptysis, } \\
\text { anorexia. }\end{array}$ & $\begin{array}{c}\text { Diffuse } \\
\text { myocardium, RA, } \\
\text { LV, aortic valve }\end{array}$ & NR & $\begin{array}{l}\text { Anterior tongue glossectomy, excision } \\
\text { of submandibular LN }\end{array}$ & None & Death \\
\hline F 58 & Tongue & $\mathrm{CP}$ & NR & CT & Hemiglossectomy and RT & $\begin{array}{l}\text { Palliative CTX and } \\
\text { immunotherapy }\end{array}$ & Death \\
\hline F 70 & Tongue & Fever \& chills & $\begin{array}{c}\text { Diffuse } \\
\text { pericardium }\end{array}$ & CT & Left hemiglossectomy, RND & Thoracotomy & Death \\
\hline F 52 & Tongue & Dull CP & RV, LV, IVS & PET & Hemiglossectomy and RND & $\begin{array}{l}\text { Pericardial } \\
\text { window and } \\
\text { palliative care }\end{array}$ & $\begin{array}{l}\text { Life expectancy }<3 \\
\text { months }\end{array}$ \\
\hline M 60 & $\begin{array}{l}\text { Base of } \\
\text { tongue }\end{array}$ & Malnutrition, pneumonia & $\begin{array}{l}\text { Anterior wall of RV } \\
\& \text { pulmonic valve }\end{array}$ & Echo & $\begin{array}{l}\text { RT and a composite tongue-jaw-neck } \\
\text { resection }\end{array}$ & Palliative care & Death \\
\hline
\end{tabular}

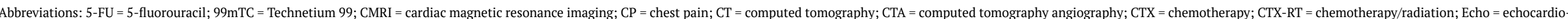

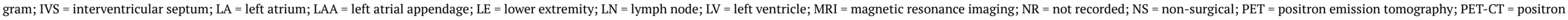
emission tomography-computed tomography; $\mathrm{RA}=$ right atrium; $\mathrm{RND}=$ radical neck dissection; $\mathrm{RT}=$ radiation therapy; $\mathrm{RV}=$ right ventricle; $\mathrm{SOB}=$ shortness of breath; $\mathrm{WL}=$ weight loss . 


\section{Supplemental Table 3. Clinical patient characteristics.}

\begin{tabular}{|c|c|}
\hline Characteristics & Data \\
\hline No. of subjects & 31 \\
\hline Male, n (\%) & $19(61.3)$ \\
\hline Female, n (\%) & $12(38.7)$ \\
\hline Mean age of diagnosis, $n$ years (range) & $53.6(23.0-77.0)$ \\
\hline Mean primary to metastasis diagnosis, $\mathrm{n}$ years (range) & $2.2(0.2-11.0)$ \\
\hline \multicolumn{2}{|l|}{ Presenting symptoms, $\mathrm{n}(\%)$} \\
\hline Chest pain & $9(29.0)$ \\
\hline Shortness of breath & $9(29.0)$ \\
\hline Syncope & $5(16.1)$ \\
\hline Weight loss & $4(12.9)$ \\
\hline Fever & $4(12.9)$ \\
\hline Oral mass & $4(12.9)$ \\
\hline Lymphadenopathy & $3(9.7)$ \\
\hline Oral pain & $3(9.7)$ \\
\hline Edema & $2(6.5)$ \\
\hline Hemoptysis & $2(6.5)$ \\
\hline Palpitations & $2(6.5)$ \\
\hline \multicolumn{2}{|l|}{ Physical exam findings, $\mathrm{n}(\%)$} \\
\hline Hypotension & $4(12.9)$ \\
\hline Fever & $4(12.9)$ \\
\hline Cardiac murmur & $3(9.7)$ \\
\hline Tachycardia & $3(9.7)$ \\
\hline \multicolumn{2}{|l|}{ Diagnostic findings, $\mathrm{n}(\%)$} \\
\hline Electrocardiography & $19(61.3)$ \\
\hline ST elevation & $12(63.2)$ \\
\hline Arrhythmia & $6(31.6)$ \\
\hline Bundle branch block & $4(21.1)$ \\
\hline T-wave inversion & $4(21.1)$ \\
\hline Echocardiography & $24(77.4)$ \\
\hline Pericardial effusion & $7(29.2)$ \\
\hline Right ventricular outflow tract obstruction & $6(25.0)$ \\
\hline Valvular dysfunction & $3(12.5)$ \\
\hline Wall motion abnormality & $2(8.3)$ \\
\hline
\end{tabular}


Supplemental Table 4. Tumor location.

\begin{tabular}{|l|l|}
\hline Characteristics & Data \\
\hline Primary tumor site, $\mathrm{n}$ (\%) & \\
\hline Tongue & $31(100.0)$ \\
\hline Cardiac metastases, $\mathrm{n}$ (\%) (1 case omitted) & $30(96.8)$ \\
\hline Right-sided metastasis & $23(76.7)$ \\
\hline Left-sided metastasis & $15(50.0)$ \\
\hline Septal metastasis & $11(36.7)$ \\
\hline Pericardial metastasis & $8(26.7)$ \\
\hline Specific location & \\
\hline Right ventricle & $17(56.7)$ \\
\hline Left ventricle & $13(43.3)$ \\
\hline Interventricular septum & $9(30.0)$ \\
\hline Right atrium & $6(20.0)$ \\
\hline Left atrium & $2(6.7)$ \\
\hline
\end{tabular}

